\title{
THE USE OF EDUCATIONAL MODELS OF DNA IN CLASSROOM BY TEACHERS OF ELEMENTARY SCHOOL
}

\author{
Chiari, F.M.; Bossolan N.R.S.; Oliveira M.R.G.; Beltramini L.M. \\ Centro de Biotecnologia Molecular Estrutural (CEPID/FAPESP) \\ Instituto de Física de São Carlos - USP, São Carlos, SP. \\ e-mail: nelma@ifsc.usp.br
}

The importance of the teaching of Biotechnology and Molecular Biology is evidenced by the progress of those areas and it generates a demand in the updating of science and biology teachers. In that sense, a project was proposed inside of the Public Education Program of FAPESP, in partnership with CBME. The goal was evaluate, among other educational tools, the contribution of the plastic models "Building the molecules of the life: DNA and RNA" in the teaching and learning of these concepts. Nine science teachers of public elementary schools had an updating course after which they elaborated a diagnosis questionnaire in order to subsidize the application of the activities in the classroom. The activities were planned seeking contextualize the subject in classroom, taking into account the difficulties detected in the diagnosis questionnaire. A sheet of notes was elaborated, where the teachers could record their observations and thoughts after the application of the activities, as well as their possibilities and the students' difficulties. These registers indicated that the teachers were satisfied with the use of the material, which made possible a deepened study on the content and a greater interest and participation of the students. It also allowed a reflection on their practice, glimpsing new ways to teach. 